\title{
BROOMRAPE IN SERBIA FROM ITS OCCURENCE TILL TODAY
}

\author{
Maširević, S. ${ }^{*}$ and Medić-Pap, S. \\ University of Novi Sad, Faculty of Agriculture, Dositej Obradović Sq. 8, \\ 21000 Novi Sad, Republic of Serbia
}

Received: July 15, 2009

Accepted: November 10, 2009

\section{SUMMARY}

\begin{abstract}
Epiphytotic occurrence of broomrape was observed in Serbia for the first time in 1951, then again at the beginning of the 1990s which continues up to date. It is hypothesized that the new race was introduced by confectionery sunflower seed. Sunflower is threatened in the north of the region of Bačka. The main foci of hazard are sunflower fields on the route Subotica - Bačka Topola, with a tendency of spreading toward Senta and Čantavir, while the second direction is toward Čonoplja and Aleksa Šantić, and then to the south. Less intensive attack has also been noticed in Banat around Padej, Itebej and Vršac. It is significant to underline that broomrape has appeared in new localities Svetozar Miletić, Mol, Novi Bečej and Zmajevo in which it had not been registered previously. In 2008, infected areas were found in Bor County (two sunflower plots) near the state border with Romania and Bulgaria.

The analysis of the parasitic population showed that broomrape in Serbia belongs to race $\mathrm{E}$ of the parasite. Continual monitoring of the broomrape population is important due to changes in race composition and evolution of new, more virulent races. The most reliable method for control of the parasite is cultivation of resistant sunflower hybrids including IMI resistant hybrids.
\end{abstract}

Key words: broomrape, methods of control, physiological races, Serbia, sunflower

\section{INTRODUCTION}

The broomrape genus (Orobanche L.) is characterized by pronounced biodiversity. Of its 99 species identified so far throughout the world, 26 have been found in Serbia. The species of Orobanche genus are highly variable and they include 56 varieties, 226 forms (a total of 308 taxons), and a number of physiological races adjusted to specific crops. Despite such high biodiversity, only 8 species are important parasite species in cultivated crops (Orobanche cumana Wallr., O. ramosa L., O. nana Noë, O. muteli Sch., O. minor Sutt., O. lutea Baumg., O. aegyptiaca Pers.

* Corresponding autor: e-mail: stevanm@polj.ns.ac.yu 
and O. crenata Forsk.). Orobanche cumana Wallr. (O. cernua Loefl.) is especially important as a parasite species in sunflowers but it is also frequently found on tomato tubers, tobacco and some weed plants. Other species of the parasite on sunflower are: O. coerulescens, O. minor, O. ramosa, O. brassicae O. aegyptica, O. crenata. The last two species from Orobanche genus are not described in Serbia (Kojić et al., 2001; Maširević and Kojić, 2002).

Broomrapes (Orobanche spp.) belong to the family Orobanchaceae, obligate parasitic flowering plants. They are native primarily to the Mediterranean region (i.e., North Africa, the Middle East, and southern Europe), and western Asia, where they cause significant crop damage (Parker and Riches, 1993). With anticipated climatic changes taking form of increased temperatures and drought in many areas of the world, Orobanche species could pose greater threats to agriculture by expanding their ranges farther north in Europe and elsewhere (Mohamed et al., 2006). Scenario analyses of the expected future climate revealed a likelihood of the potential range of Orobanche crenata to expand to temperate Europe (Sauerborn and Grenz, 2005). Climate warming could also influence the broomrape distribution in our country (Maširević and Medić-Pap, 2009).

According to Aćimović (1977), broomrape was described in Serbia for the first time in 1951. Since that period it has been appearing with varying intensity almost every year but since the 1990s broomrape it has been causing significant damage in susceptible hybrids. Extent of yield losses depends on attack intensity of which may range from 5 to 100 \% (Maširević, 2001). Broomrape seeds remain viable for 8-12 years. In addition to this huge infectious potential, another significant problem is caused by the heterogeneity of its population, i.e., by the existence of multiple physiological races, each specific to a particular sunflower region. The occurrence of new broomrape races has been reported in recent years in other countries (Romania, Bulgaria, Turkey, Spain, Russia).

It is important to determinate the areas infested by Orobanche cumana as well as its races in the Vojvodina Province as the main sunflower production region in Serbia.

\section{MATERIALS AND METHODS}

Orobanche seeds have been collected from a large number of sunflower fields in Vojvodina region. Whole plants were taken at maturity stage and were put in paper bags. Paper bags with plants were stored under laboratory conditions in dry and illuminated place due to additional ripening. After twenty days, mature seeds were classified according to locality and then determined for race composition. Seed dormancy was broken by storing seeds in cold chamber at $+4^{\circ} \mathrm{C}$ for 60 days. Race composition was tested on differential lines in greenhouse.

Seeds of broomrape and sunflower were put in plastic tubes $13 \mathrm{~cm}$ in diameter, $12 \mathrm{~cm}$ high) which were filled by sand and perlite mixture. Broomrape seeds were 
placed under sunflower seeds, so that sunflower roots must penetrate into the zone of broomrape seed. Test results were scored at one-month intervals. Material was evaluated according to abscence/presence of broomrape plants. Presence of only one broomrape plant on sunflower root classifies that genotype as susceptible.

Other tests were conducted under field conditions in Bačka Topola and Svetozar Miletić. In highly infested plots under conditions of repeated sunflower sowing, susceptible and resistant genotypes could be distinguished with accuracy. Evaluation of sunflower genotypes was conducted on the basis of the number of broomrape plants per sunflower plant and percent of infested sunflower plants.

\section{RESULTS AND DISSCUSION}

According to our results, sunflower is threatened in the north of Bačka region. The main infestation foci are sunflower fields on the route Subotica - Bačka Topola, with a tendency of spreading toward Senta and Čantavir. Second direction is toward Čnoplja and Aleksa Šantić, and then to the south. Only in Subotica region (Ljutovo) 5000 ha are threatened. Less intensive attacks have also been observed in Banat region, around Padej, Itebej and Vršac. It is significant to underline that broomrape has been registered in new localities Svetozar Miletić, Mol, Novi Bečej and Zmajevo, whereat which it had not been registered previously. The analysis of racial composition showed that broomrape in Serbia belongs to race E. Most sunflower hybrids in our country and abroad are susceptible to race E.

Infested areas were also found in Bor County near the state border with Romania and Bulgaria (according the data submitted to Directorate for Plant Protection). It is necessary to carefully investigate the racial composition of broomrape in Bor region because new broomrape races have been determined in Romania and Bulgaria.

On the basis of the inspection of a large number of small- and large-plot trials and commercial sunflower fields, it was concluded that the damage caused by broomrape in 2008 did not have significant influence on the total sunflower production. However, in some plots and in some parts of plots, significant yield reductions were registered. Large concentrations of broomrape plants were observed in isolated spots in some plots.

Data shown in Tables 1 and 2 clearly indicate that in both investigated localities (Bačka Topola and Svetozar Miletić) there was high similarity between the parasite populations. However, the population in Svetozar Miletić manifested a higher aggressiveness. High resistance of the hybrid Bačvanin was noted in a number of production trials and it should be object of further investigations.

Changes in racial composition have been observed in neighboring countries. The changes were especially noticeable in recent years. In Romania, in the regions of Constanca, Tucea and Braila, six races of broomrape were determined, A, B, C, D, E and F (Pacureanu, 2005). A new highly virulent broomrape population has 
attacked sunflowers in Romania in 2006. Many commercial hybrids belonging to different companies exhibited susceptibility to the parasite. The 2008 test results indicated that a new and different virulent population of the parasite has occurred again (Pacureanu-Joita, 2008).

Table 1: Occurrence of broomrape on some sunflower hybrids in Bačka Topola and Svetozar Miletić localities

\begin{tabular}{lcccc}
\hline & \multicolumn{2}{c}{ Bačka Topola } & \multicolumn{2}{c}{ Svetozar Miletić } \\
\cline { 2 - 5 } Hybrid & $\begin{array}{c}\text { Percent of } \\
\text { infested plants }\end{array}$ & $\begin{array}{c}\text { Number of } \\
\text { broomrape plants } \\
\text { per sunflower plant }\end{array}$ & $\begin{array}{c}\text { Percent of } \\
\text { infested plants }\end{array}$ & $\begin{array}{c}\text { Number of } \\
\text { broomrape plants } \\
\text { per sunflower plant }\end{array}$ \\
\hline NS-H-DUKAT & 100 & 13 & 100 & 23 \\
NS-H-01 & 98 & 14 & 100 & 32 \\
NS-H-111 & 97 & 11 & 100 & 16 \\
NS-H-452 & 100 & 11 & 99 & 17 \\
BAČVANIN & 4.3 & 9 & 7.4 & 8 \\
NS-H-43 & 99 & 16 & 99 & 22 \\
NS-H-LABUD & 100 & 19 & 100 & 31 \\
KRAJIŠNIK & 100 & 19 & 100 & 32 \\
NS-H-17 & 97 & 21 & 100 & 24 \\
BANAĆANIN & 100 & 26 & 100 & 26 \\
DELIJA & 99 & 32 & 99 & 40 \\
NS-H-VELJA & 100 & 22 & 100 & 37 \\
\hline
\end{tabular}

According to the reaction of differential lines during a 3-year FAO trial (20022005) in Bulgaria, three races of parasite were determined, D, E, and F. Race E had the widest distribution area and it was present in all sunflower production regions in that country (Shindrova, 2005).

Table 2: Occurrence of broomrape on some experimental sunflower hybrids in Bačka Topola and Svetozar Miletić localities

\begin{tabular}{lcccc}
\hline & \multicolumn{2}{c}{ Bačka Topola } & \multicolumn{2}{c}{ Svetozar Miletić } \\
\cline { 2 - 5 } Hybrid & $\begin{array}{c}\text { Percent of } \\
\text { infested plants }\end{array}$ & $\begin{array}{c}\text { Number of } \\
\text { broomrape plants } \\
\text { per sunflower plant }\end{array}$ & $\begin{array}{c}\text { Percent of } \\
\text { infested plants }\end{array}$ & $\begin{array}{c}\text { Number of } \\
\text { broomrape plants } \\
\text { per sunflower plant }\end{array}$ \\
\hline NS-H-925 & 3,9 & 5 & 10 & 9 \\
NS-H-928 & 98 & 20 & 99 & 32 \\
NS-H-111 & 80 & 7 & 89 & 12 \\
NS-H-931 & 99 & 24 & 100 & 45 \\
BAČVANIN & 3,7 & 3 & 4 & 4 \\
\hline
\end{tabular}

Latest data from Turkey indicate the occurrence of a new race in addition to the 5 present races (A, B, C, D and E). It is important to emphasize that brhe oomrape area in Turkey increased from $2 \%$ in 1995 to $35 \%$ in 2002 . According to the investigations of Kaya et al. (2004a) the new broomrape race (race F) was determinated at $60 \%$ of the sunflower production area. The same authors claim that the Turkish race $\mathrm{F}$ is significantly more virulent from those identified in other countries. It is 
considered that in Trakya, the European part of Turkey, thereprobably exist three unindentified broomrape species (Kaya et al., 2004b). Since the magnitude of the broomrape problem increases every year in Turkey, National Broomrape Project has been organized in 2006which gathers several governmental institutes and universities. After the completion of the project, producers will be to be educated how to apply preventive measures to stop the dispersal of broomrape seeds (Bulbul et al., 2008).

According to investigations conducted in Russia, new broomrape races have been registered in this country. These races are different from the Romanian race $F$ and the Turkish races $\mathrm{G}$ and $\mathrm{H}$ (Antonova, personal communication).

Five races have been reported in Spain (Alonso, 1998). Races C and E are dominant, while presence of race $B$ has not been confirmed. In recent years, in south of Spain, precence of a new race, $\mathrm{F}$, was determined. Race $\mathrm{F}$ can infect genotypes which possess $\mathrm{Or}_{1}-\mathrm{Or}_{5}$ genes that confer resistance to races A to E (Dominguez et al., 1996, Melero-Vara, 1997). In 2008, a highly virulent broomrape infestation focal point (about $300 \mathrm{~m}^{2}$ ) has been detected in a sunflower plot near Medina del Campo (Valladolid), south of the center of Castilla-León area. Racial determination has proved that these broomrape inoculums belong to race $\mathrm{F}$ (Fernández-Escobar et al., 2008). As a rule, introduction of new resistance is frequently followed by the occurrence of new virulent races overcoming that resistance. To overcome this problem, combined strategy to O. cumana control was attempted in Spain. The strategy includes the use of IMI sunflower cultivars, combination of vertical and horizontal resistance mechanisms in the same genotype in order to develop a more durable resistance, molecular studies to identify QTLs associated with broomrape resistance genes to facilitate the pyramiding of different resistance genes and the combination of different resistance mechanisms, and the study of the variability and racial composition of Spanish sunflower broomrape populations using classical and molecular methods (Fernández-Martínez et al., 2008).

Identification of species and races from Orobanche genus is difficult due to their morphological variability which can be influenced by host plant, the fact that these plants do not perform photosyntesis, have no leaves and have weak, poorly developed root system (Musselman, 1994). In recent years RAPD markers have been successfuly used in identification of species from this genus in Israel (Katzir et al., 1996) and Egypt (Zeid et al. 1997), as well as in evalution of genetic variability within the Orobanche species (Joel et al., 1998). Using RAPD markers, Gange et al. (1998) obtained results that populations were well structured and organized into two distinct groups (one group corresponding to the East European countries, Bulgaria, Romania and Turkey, and the other group corresponding to Spanish populations) and could have a monophyletic origin. These results are discussed in relation to the applied uses of RAPD markers in the determination of true O. cumana races instead of populations. 
Ciuca et al. (2004), on the basis of an investigation of ten O. cumana populations of different geographic origin by RAPD markers, indicated significant similarity between broomrape populations from Romania and Serbia.

Gagne et al. (2000) showed that AFLP markers have a higher degree of resolution for discriminating closely related germplasms and appear to be a suitable technique for study of the genetic variability in $O$. cumana.

Together with identification of new races by sophisticated molecular techniques there are constant investigations for new sources of resistance to broomrape because the most efficient way to control broomrape is cultivation of resistant hybrids. In breeding process it is important to use genetically divergent material of different origin.

Continual investigations lof genotype susceptabily are conducted in Russia, Spain, Bulgaria, Romania, Turkey, France and Serbia. Wild species from the genus Helianthus could be used as possible sources in breeding for resistance (gene $\mathrm{Or}_{5}$ originated from $H$. tuberosus). High level of resistance to race $\mathrm{F}$ has been observed in wild populations as well as in cultivated genotypes (Fernandez-Martinez et al., 2000). Allelic crosses between race F resistant lines, as well as crosses between race $\mathrm{F}$ resistant lines and race $\mathrm{E}$ resistant lines showed different dominant reactions and inheritance mechanisms for broomrape (Perez-Vich et al., 2004).

Continual monitoring of the broomrape population in Serbia is neccesery in order to identify new, more virulent races of parasite in due time. Sowing of healty sunflower seed and import of seed from uninfested regions are important preventive mesaures for control of the parasite.

Several plant pathogens have been reported to attack specifically Orobanche. So far no fungus is commercially used against Orobanche. Linke et al. (1992) isolated nine genera of fungi (16 species) from O. crenata in Syria. In preliminary host-specificity tests on 11 crops, Ulocladium atrum appeared to be host-specific and showed promise as a biological control agent, but a requirement for high humidity may limit its usefulness. Also there was aninvestigation on the use of Fusarium oxysporum in biological control of broomrape in sunflower and tobbaco (Parker and Riches, 1993). The broomrape-fly Phytomyza orobanchia was widely used for Orobanche control in the Soviet Union and some East European countries (Girling et al., 1979). No outstanding success has so far been achieved using this biological agent, mainly because of some hyperparasites that attack Phytomyza.

All broomrape races can be successfully controlled by chemical means, namely by growing IMI-resistant hybrids (RIMI) in synchrony with the application of appropriate imidazolinone-based herbicides. (Škorić and Jocić, 2005). 


\section{CONCLUSION}

The analysis of the parasitic population showed that broomrape in Serbia belongs to race E. Continual monitoring of the broomrape population in Serbia is vry important due to changes in race composition and evolution of new more virulent races in neighbouring countries and also because climate changes are favourable for expansion of Orobanche species to lage areas. All quarantine measures have to be taken. Because of easy dispersal of their small seeds, broomrape control is difficult. Strategy for broomrape control should be cultivation of resistant sunflower hybrids including IMI resistant hybrids and broomrape tolerant hybrids which suppress and reduce weed population and epidemics, combination of vertical and horizontal resistance in the same genotype in order to develop more durable resistance mechanisms, molecular studies to identify broomrape resistance genes, determination of new sources of resistance by testing wild Heliathus species and the study of the variability and race composition of broomrape populations using classical and molecular methods.

\section{REFERENCES}

Aćimović, M., 1977. Distribution of important sunflower diseases in Yugoslavia. Periodical of Scientific research on field and vegetable crops, Faculty of Agriculture, Institute of Field and Vegetable Crops, Novi Sad, Yugoslavia, pp. 1-16.

Alonso, L. C., 1998. Resistance to Orobanche and resistance breeding. Current problems of Orobanche Researchs, Proc. of Int. Orobanche Workshop, Albena, pp. 233-259.

Bülbül, F., Aksoy, E., Uygur, S., and Uygur, N., 2008. Broomrape (Orobanche spp.) Problem in the Eastern Mediterranean Region of Turkey. International Symposium on Broomrape (Orobanche spp.) in Sunflower. November 30 - December 3, 2008, Antalya, Turkey pp. 14-15.

Ciuca, M., Pacureanu, M. and Iuora M. 2004., RAPD Markers for Polymorphisam Identification in Parasitic Weed Orobanche cumana Wallr. Romanian Agricultural Research pp. 29-32.

Dominguez, J., Melero-Vara, J.M. and Refoyo, A., 1996. Virulence groups of Orobanche cernua in Andalusia (southern Spain) 633-637. In: M. Moreno et al. [ed.] Advances in parasitic plant research. Proc. Int. Symp. In Parasitic Weed, $6^{\text {th }}$, Cordoba, Spain. 16-18 Apr. 1996. Congresos y Jornadas 36/96. Direccion General de Invegastigacion Agraria, Consejeria de Agricultura y Pesca, Sevilla, Spain.

Fernández-Escobar, J., Rodríguez-Ojeda, M.I., Fernández-Martínez, J.M. and Alonso, L.C., 2008. Sunflower broomrape (Orobanche cumana Wallr.) in Castilla-León, a traditionally non broomrape infested area in Northern Spain. International Symposium on Broomrape (Orobanche spp.) in Sunflower, November 30 - December 3, 2008, Antalya, Turkey pp. 21-22.

Fernandez-Martinez, J. Melero-Vara, J., Munoz-Ruz, J., Ruso, J. and Dominguez, J., 2000. Selection of wild and cultivated sunflower for resistance to a new broomrape race that overcomes the $\mathrm{Or}_{5}$ gene. Crop. Sci. 40: 550-555.

Fernández-Martínez, J.M., Domínguez, J., Pérez-Vich, B. and Velasco L., 2008. Ongoing Research Strategies for Sunflower Broomrape Control in Spain International Symposium on Broomrape (Orobanche spp.) in Sunflower November 30 - December 3, 2008, Antalya, Turkey pp. 16-17.

Gagne, G., Roeckel-Drevet, P., Grezes-Besset, B., Shindrova, P., Ivanov, P., Grand-Ravel, C., Vear, F., Tourvieille de Labrouhe, D., Charmet, G. and Nicolas P., 1998. Study of the variability and evolution of Orobanche cumana populations infesting sunflower in different European countries. Theor Appl Genet 96: 1216-1222.

Gagne, G., Roeckel-Drevet, P., Grezes-Besset, B., Shindrova, P., Ivanov, P., Grand-Ravel, C., Vear, F., Charmet, G. and Nicolas, P. 2000. Amplifed Fragment Length Polymorphism AFLP as Suitable Markers to Study Orobanche cumana Genetic Diversity. Phytopathology 148: 457-459. 
Girling, D.J., Greathead D.J., Mohyuddin, A.I. and Sankaran, T., 1979. The potential for biological control in the suppression of parasitic weeds. Biocontrol News and Information, sample issue: 7-16.

Joel, D.M., Benharrat, H., Portnoy , H.V. and Thalouarn, P., 1998. Molecular markers for Orobanche species - new approaches and their potential uses. Proc. of $4^{\text {th }}$ Int. Workshop on Orobanche, Albena, pp. 115-124.

Katzir, N., Portnoy, V., Tzuri, G., Castejon-Munoz, M. and Joel, D.M., 1996. Use of random amplified polymorphic DNA (RAPD) markers in the study of the parasitic weed Orobanche. Theoretical and Applied Genetics 93: 367-372.

Kaya, Y., Demirci, M. and Evci, G., 2004a. Sunflower (Heliathus annuus L.) breeding in Turkey from broomrape (Orobanche cernua Loeffl.) and herbicide resistance. Helia 27(40): 199-210.

Kaya, Y., Evci, G., Pekcan, V. and Gucer, T., 2004b. Determinig new broomrape-infested areas, resistance lines and hybrides in Trakya Region of Turkey. Helia 27(40): 211-218.

Kojić, M., Maširević, S. and Jovanović, D., 2001. Distribution and biodiversity of broomrape (Orobanche L.) worldwide and in Serbia, Helia 24(35): 73-92.

Linke, K.H., Schneibel, C., Saxena, M.C. and Sauerborn, J., 1992. Fungi occurring on Orobanche spp. and their preliminary evaluation for Orobanche control. Tropical Pest Management 38:127-130.

Maširević, S., 2001. Širenje volovoda na suncokretu i analiza populacije parazita. Zbornik radova Naučnog Instituta za ratarstvo i povrtarstvo, Novi Sad. Sveska 35: 235-241.

Maširević, S., Kojić, M. (2002): Rasprostranjenje i biodiverzitet volovoda (Orobanche L.) u Evropi i kod nas. Zbornik radova Naučnog Instituta za ratarstvo i povrtarstvo, Novi Sad. Sveska 36: 161-168.

Maširević S. and Medić-Pap, S., 2009. Prognosis service in plant protection in conditions of climate change. Klimatske promene u poljoprivrednoj proizvodnji u Srbiji. Drugi nacionalni skup o očekivanim promenama klime u Vojvodini i njihovim efektima. pp. 6-7.

Melero-Vara, J.M., 1997. El jopo del girasol: Evolucion racial y desarrolo de resistencia genetica. In: Proc. Natl. Seed Symp., $4^{\text {th }}$, Sevilla, Spain. 5-7 Nov. 1997. Junta de Andalucia Spain, pp. 373-382.

Mohamed, K.I., Papes, M., Williams, R., Benz, B.W., Reterson, A.T., 2006. Global Invasive Potential of 10 Parasitic Witch weeds and Related Orobanchaceae AMBIO: A Journal of the Human Environment 35(6):281-288.

Mohamed, K.I., Papes, M., Williams, R., Benz, B.W., Reterson, A.T., 2006.

Musselman, L.J., 1994. Taxonomy and spread of Orobanche. Biology and management of Orobanche. In: Pieterse, A.H., Verkleij, J.A.C. ter Borg, S.J. [Eds.], Proceedings of the $3^{\text {rd }}$ international workshop on Orobanche and related Striga research, Amsterdam, Netherlands, November 8-12, Amsterdam, Netherlands, Royal Tropical Institute, pp. 27-35.

Pacureanu-Joita, M., 2005. Orobanche sp. in Romania: The impact of the new races of the parasite in sunflower crop. COST Action 849, Parasitic Plant Management in Sustainable Agriculture WG 1+4 Workshop on Means for Limiting Orobanche Propagation and Dispersal in Agricultural Fields, December 4-6, Newe-Yaar Research center, Israel, pp. 10.

Pacureanu Joita, M., Raranciuc, S., Sava, E., Petcu, E., Babeanu, N., and Popa O., 2008. Virulence and aggressiveness of sunflower broomrape (Orobanche cumana Wallr.) populations, in Europe. International Symposium on Broomrape (Orobanche spp.) in Sunflower 30.11-3.12 Antalya Turkey, pp. 28.

Parker, C. and Riches, C.R., 1993. Parasitic Weeds of the World: Biology and Control. CAB International, Wallingford, UK, pp. 1-332.

Perez-Vich, B., Aktouch, B., Mateos, A., Velasco, L., Jan, C., Fernandez, J., Domiguez, J. and Fernandez-Martinez, J., 2004. Dominance relationships for genes conferring resistance to broomrape (Orobanche cumana Wallr.) in sunflower. Helia 27(40): 183-192.

Sauerborn, J. and Grenz, J.H., 2005. Potential distribution of Orobanche under current and predicted future climate COST Action 849, Parasitic Plant Management in sustainable Agriculture WG1 + 4 Workshop on Means for limiting Orobanche propagation and dispersal in agricultural fields December 4-6, Newe-Yaar Research center, Israel, pp. 23.

Shindrova, P. 2005. FAO working group sunflower diseases - Subgroup: Broomrape (Orobanche cumana Wallr.) in Bulgaria. Progress reports for the period 2002-2005.

Škorić , D. and Jocić, S., 2005. Broomrape (Orobanche cumana Wallr.) and its possible control by genetic and chemical means. Uljarstvo 36(1-2): 15-22.

Zeid, M., Madkour, M., Koraiem, Y., Nawar, A., Soliman, M. and Zaitoun, F., 1997. Molecular studies on Orobanche. Journal of Phytopathology 141: 351-355. 


\title{
SITUACIÓN DEL JOPO EN SERBIA DESDE SU APARICIÓN HASTA NUESTROS DÍAS
}

\author{
RESUMEN
}

La propagación del jopo en Serbia fue anunciada por vez primera en 1951 y de nuevo a comienzo de los años noventa y continúa hasta la fecha. Se considera que la nueva raza se introdujo junto con semillas de girasol confitero. El girasol está en peligro de extinción en el norte de la región de Bačka. Los principales focos de riesgo son las zonas girasoleras en la ruta SuboticaBačka Topola, con una tendencia de propagación hacia Centa y Čantavir, mientras que la segunda dirección es hacia Čonoplja y Aleksa Šantić y, luego, hacia el sur. Los ataques menos intensos se anunciaron en Banat alrededor de Padej, Itebej y Vršac. Es importante destacar que el jopo apareció en nuevas localidades: Svetozar Miletić, mol, Novi Bečej y Zmajevo, en las que no había sido detectado previamente. Durante 2008, se detectaron áreas infectadas en la provincia Bor (dos parcelas de girasol) cerca de la frontera con Rumania y Bulgaria. El análisis de población mostró que en Serbia el jopo pertenecía a la raza E. El monitoreo constante de la población del jopo es muy importante debido a los cambios en la composición racial y la evolución hacia nuevas razas más virulentas. El método más confiable para el control del parásito es el cultivo de híbridos resistentes así como los híbridos resistentes a los herbicidas IMI.

\section{STATUT DE l'Orobanche EN SERBIE DEPUIS SON APPARITION JUSQU'À CE JOUR}

RESUME

La diffusion épiphytique de l'Orobanche a été observée pour la première fois en Serbie en 1951, puis au début des années 90 et continue à ce jour. Il est supposé qu'une nouvelle race a été introduite par les tournesols de bouche.

Le tournesol est menacé au nord de la région de Bačka. Les principales zones à risque sont les secteurs de culture sur la route de Subotica - Bačka Topola, avec une tendance à la propagation vers Senta et Čantavir, une deuxième en direction de Čonoplja et Aleksa Šantić et enfin une vers le sud.

Des attaques moins intenses ont également été notées à Banat autour de Padej, d'Itebej et de Vršac. Il est important de souligner que l'Orobanche est apparue dans de nouvelles localités (Svetozar Miletić, Mol, Novi Bečej et Zmajevo) dans lesquelles elle n'avait pas été vue précédemment.

En 2008, des secteurs infestés ont été trouvés dans le comté de Bor (deux parcelles) près de la frontière avec la Roumanie et la Bulgarie.

L'analyse de cette population du parasite en Serbie a montré que l'Orobanche appartenait à la race $\mathrm{E}$. La surveillance constante de la population d'Orobanche est essentielle en raison des changements dans la composition des populations et de l'évolution vers de nouvelles races plus virulentes.

La méthode la plus fiable pour le contrôle du parasite est la mise en culture d'hybrides de tournesol IMI présentant une résistance aux Imidazoles. 
